\title{
Coordination of the Bis(pyridyl)methyl Substituent to Group 1 and 13 Metals
}

\author{
Heinz Gornitzka and Dietmar Stalke* \\ Institut für Anorganische Chemie der Universität Göttingen, Tammannstrasse 4, \\ D-37077 Göttingen, Germany
}

Received May 23, $1994^{\otimes}$

\begin{abstract}
The bis(pyridyl)methyl derivatives [(thf $\left.)_{2} \mathrm{Li}\left(2-\mathrm{NC}_{5} \mathrm{H}_{4}\right)_{2} \mathrm{CH}\right],\left[\mathrm{H}_{2} \mathrm{C}\left(2-\mathrm{NC}_{5} \mathrm{H}_{4}\right)_{2} \mathrm{Li}\left(2-\mathrm{NC}_{5} \mathrm{H}_{4}\right)_{2}\right.$ $\mathrm{CH}],\left[\mathrm{Li}(12 \text {-crown-4 })_{2}\right]\left[\mathrm{Li}\left\{\left(2-\mathrm{NC}_{5} \mathrm{H}_{4}\right)_{2} \mathrm{CH}\right\}_{2}\right],\left[\mathrm{Na}(\text { thf })_{6}\right]\left[\mathrm{Li}\left\{\left(2-\mathrm{NC}_{5} \mathrm{H}_{4}\right)_{2} \mathrm{CH}\right\}_{2}\right],\left[\mathrm{Me}_{2} \mathrm{Al}\left(2-\mathrm{NC}_{5} \mathrm{H}_{4}\right)_{2}-\right.$ $\mathrm{CH}]$, and $\left[\mathrm{Me}_{2} \mathrm{Ga}\left(2-\mathrm{NC}_{5} \mathrm{H}_{4}\right)_{2} \mathrm{CH}\right]$ have been synthesized and characterized by low-temperature $\mathrm{X}$-ray structure determination. Although deprotonated at the central carbon atoms, they are only formally carbanions. All experimental structural parameters indicate that they are better described as amides. The bis(pyridyl)methyl ligand coordinates lithium, aluminum, and gallium with both nitrogen ring atoms. All anions are planar and fully conjugated. Two anions coordinated to a single lithium atom seem favorable, because this structural motif of the overall anion is present in the structure of a lithium lithiate and a sodium lithiate. In the first structure, the lithium cation is complexed by two crown ether molecules, in the latter, the sodium cation is complexed by six thf molecules. Crystals of this compound melt at about $-30^{\circ} \mathrm{C}$. At $-80^{\circ} \mathrm{C}$, it is possible to isolate an intermediate with lithium coordinated by one bis(pyridyl)methyl anion and one molecule bis(pyridyl)methane, which donates the lithium atom like a nitrogen base. This intermediate gives direct access to the structural comparison of the starting material and the anion. In all metal complexes, the double bonds of the anion are localized, regardless of group 1 or group 13 metals. Lithium, aluminum, and gallium match in size and fit the bite of the bis(pyridyl)methyl ligands. The bigger sodium cation is complexed by thf molecules.
\end{abstract}

\section{Introduction}

Recently, we have been interested in comparing the coordinative behavior of the triphenylmethyl carbanion ${ }^{1}$ to that of the diphenylpyridylmethyl substituent ${ }^{2}$ toward alkali metals. While the $\mathrm{Ph}_{3} \mathrm{C}^{-}$anion is capable of delocalizing the negative charge to a maximum extent, leaving the potential energy surface quite flat, ${ }^{3-5}$ $\mathrm{Ph}_{2}\left(2-\mathrm{NC}_{5} \mathrm{H}_{4}\right) \mathrm{C}^{-}$seems to have a distinct minimum. The harder cations $\mathrm{Li}^{+}$and $\mathrm{Na}^{+}$are located above the central carbon atom ${ }^{6-9}$ in $\mathrm{Ph}_{3} \mathrm{C}^{-}$, but the bigger cations like $\mathrm{K}^{+}$, $\mathrm{Rb}^{+}$, and $\mathrm{Cs}^{+}$are located above the center of one phenyl ring. ${ }^{1}$ The $\mathrm{Ph}_{2}\left(2-\mathrm{NC}_{5} \mathrm{H}_{4}\right) \mathrm{C}^{-}$-anion seems only formally to be a carbanion. The negative charge, however, is almost entirely located at the nitrogen atom. Not only $\mathrm{Li}^{+}$and $\mathrm{Na}^{+}$but also $\mathrm{K}^{+}$are coordinated to the nitrogen atom of the $\mathrm{Ph}_{2}\left(2-\mathrm{NC}_{5} \mathrm{H}_{4}\right) \mathrm{C}$ amide. ${ }^{2}$ With this in mind, we have turned our attention to the $\left(2-\mathrm{NC}_{5} \mathrm{H}_{4}\right)_{2} \mathrm{CH}^{-}$ anion. ${ }^{10}$

$\left[\left(\right.\right.$ thf $\left._{2} \mathrm{Li}\left(2-\mathrm{NC}_{5} \mathrm{H}_{4}\right)_{2} \mathrm{CH}\right](\mathbf{1}),\left[\mathrm{H}_{2} \mathrm{C}\left(2-\mathrm{NC}_{5} \mathrm{H}_{4}\right)_{2} \mathrm{Li}\left(2-\mathrm{NC}_{5}-\right.\right.$ $\left.\left.\mathrm{H}_{4}\right)_{2} \mathrm{CH}\right](\mathbf{2}),\left[\mathrm{Li}(12 \text {-crown-4 })_{2}\right]\left[\mathrm{Li}\left\{\left(2-\mathrm{NC}_{5} \mathrm{H}_{4}\right)_{2} \mathrm{CH}\right\}_{2}\right](3)$,

${ }^{\otimes}$ Abstract published in Advance ACS Abstracts, October 1, 1994. (1) Hoffmann, D.; Bauer, W.; Schleyer, P. v. R.; Pieper, U.; Stalke, D. Organometallics 1993, 12, 1193 .

(2) Pieper, U.; Stalke, D. Organometallics 1993, 12, 1201.

(3) Hehre, W. J.; Radom, L.; Schleyer, P. v. R.; Pople, J. Ab initio Molecular Orbital Theory; Wiley: New York, 1986; $466 \mathrm{ff}$

(4) (a) Schleyer, P. v. R. Pure Appl. Chem. 1983, 55, 355. (b) Schleyer, P. v. R. Ibid. 1984, 56, 151 .

(5) (a) Streitwieser, A. Jr. Acc. Chem. Res. 1984, 17, 353. (b) Boche, G.; Etzrod, H.; Massa, W.; Baum, G. Angew. Chem. 1985, 97, 858; Angew. Chem., Int. Ed. Engl. 1985, 24, 863.

(6) Brooks, J. J.; Stucky, G. D. J. Am. Chem. Soc. 1972, 94, 7333.

(7) Bartlett, R. A.; Dias, H. v. R.; Power, P. P. J. Organomet. Chem. 1988, 341,1

(8) Olmstead, M. M.; Power, P. P. J. Am. Chem. Soc. 1985, 107, 2174.

(9) Köster, H.; Weiss, E. J. Organomet. Chem. 1979, 168, 273.

(10) Gornitzka, H.; Stalke, D. Angew. Chem. 1994, 106, 695; Angew. Chem., Int. Ed. Engl. 1994, 33, 693 .

0276-7333/94/2313-4398\$04.50/0 and $\left[\mathrm{Na}(\text { thf })_{6}\right]\left[\mathrm{Li}\left\{\left(2-\mathrm{NC}_{5} \mathrm{H}_{4}\right)_{2} \mathrm{CH}\right\}_{2}\right](4)$ have been synthesized and characterized by low-temperature $\mathrm{X}$-ray structures. To study the coordination of the $\left(2-\mathrm{NC}_{5} \mathrm{H}_{4}\right)_{2}$ $\mathrm{CH}$ ligand toward group 13 metals, we have synthesized $\left[\mathrm{Me}_{2} \mathrm{Al}\left(2-\mathrm{NC}_{5} \mathrm{H}_{4}\right)_{2} \mathrm{CH}\right](5)$ and $\left[\mathrm{Me}_{2} \mathrm{Ga}\left(2-\mathrm{NC}_{5} \mathrm{H}_{4}\right)_{2} \mathrm{CH}\right]$ (6). Their structures are presented as well.

\section{Results and Discussion}

Preparation of 1-6. Bis(2-pyridyl)methane was prepared according to the literature. ${ }^{11-13}$ Compound 1 was synthesized by adding $n$-butyllithium to a bis(2pyridyl)methane solution (eq 1).

$$
\begin{aligned}
\left(2-\mathrm{NC}_{5} \mathrm{H}_{4}\right)_{2} \mathrm{CH}_{2}+{ }^{n} \mathrm{BuLi} \stackrel{-80^{\circ} \mathrm{C} \text { in THF }}{\longrightarrow} \\
{\left[(\text { thf })_{2} \mathrm{Li}\left(2-\mathrm{NC}_{5} \mathrm{H}_{4}\right)_{2} \mathrm{CH}\right]+{ }^{n} \mathrm{BuH} } \\
1
\end{aligned}
$$

If bis(2-pyridyl)methane is reacted with $n$-butyllithium in hydrocarbons like toluene, the intermediate 2 can be isolated at $-80^{\circ} \mathrm{C}$. In 2,1 equiv of the starting material acts as a donor base (well-known in lithium chemistry; like tmeda $\mathrm{Me}_{2} \mathrm{NCH}_{2} \mathrm{CH}_{2} \mathrm{NMe}_{2}$ ), while the second forms the deprotonated anion (eq 2). 2 decomposes at temperatures slightly higher than $-50^{\circ} \mathrm{C}$. The colorless crystals turn into a dark brown oil. 1 was reacted with 1 equiv of 12-crown-4. The lithium lithiate 3 was isolated (eq 3). To achieve metal exchange, 1 was

(11) Osuch, C.; Levine, R. J. Am. Chem. Soc. 1956, 78, 1723.

(12) Canty, A. J.; Minchin, N. J. Aust. J. Chem. 1986, 39, 1063.

(13) Keene, F. R.; Tiekink, E. R. T. Acta Crystallogr., Sect. C 1990, 46,1562 .

(14) For review: Gregory, K.; Schleyer, P. v. R.; Snaith, R. Adv. Inorg. Chem. 1991, 37, 47. 


$$
\begin{aligned}
& 2\left(2-\mathrm{NC}_{5} \mathrm{H}_{4}\right) \mathrm{CH}_{2}+2^{n} \mathrm{BuLi} \stackrel{-80^{\circ} \mathrm{C} \text { in toluene }}{\longrightarrow} \\
& {\left[\mathrm{H}_{2} \mathrm{C}\left(2-\mathrm{NC}_{5} \mathrm{H}_{4}\right)_{2} \mathrm{Li}\left(2-\mathrm{NC}_{5} \mathrm{H}_{4}\right)_{2} \mathrm{CH}\right]+} \\
& { }^{n} \mathrm{BuLi}+{ }^{n} \mathrm{BuH}(2) \\
& 2\left[(\text { thf })_{2} \mathrm{Li}\left(2-\mathrm{NC}_{5} \mathrm{H}_{4}\right)_{2} \mathrm{CH}\right]+ \\
& 1 \\
& 2 \text { (12-crown-4) }-80^{\circ} \mathrm{C} \text { in hexane/THF } \\
& {\left[\mathrm{Li}(12 \text {-crown-4 })_{2}\right]\left[\mathrm{Li}\left\{\left(2-\mathrm{NC}_{5} \mathrm{H}_{4}\right)_{2} \mathrm{CH}\right\}_{2}\right]}
\end{aligned}
$$

reacted in a $1: 1$ ratio with $\mathrm{NaO}^{t} \mathrm{Bu}$. Only 0.5 equiv of $\mathrm{Li}^{+}$in 1 was substituted by $\mathrm{Na}^{+}$, resulting in the sodium lithiate 4 (eq 4). The colorless crystals of 4 melt at ca.

$$
\begin{gathered}
2\left[\left(\text { thf }_{2} \mathrm{Li}\left(2-\mathrm{NC}_{5} \mathrm{H}_{4}\right)_{2} \mathrm{CH}\right]+2 \mathrm{NaO}{ }^{t} \mathrm{Bu} \stackrel{\text { room temp in } \mathrm{THF}}{\longrightarrow}\right. \\
\quad \begin{array}{l}
\mathbf{T} \\
{\left[\mathrm{Na}\left(\text { thf }_{6}\right]\left[\mathrm{Li}\left\{\left(2-\mathrm{NC}_{5} \mathrm{H}_{4}\right)_{2} \mathrm{CH}\right\}_{2}\right]+\mathrm{NaO}^{t} \mathrm{Bu}+\mathrm{LiO}^{t} \mathrm{Bu}\right.}
\end{array}
\end{gathered}
$$$$
4
$$

$-30^{\circ} \mathrm{C}$. 1 was reacted with dimethylaluminum chloride and dimethylgallium chloride to give the dimethylaluminum bis(pyridyl)methyl (5) and dimethylgallium bis(pyridyl)methyl (6) derivatives (eq 5).

$$
\begin{gathered}
{\left[(\text { thf })_{2} \mathrm{Li}\left(2-\mathrm{NC}_{5} \mathrm{H}_{4}\right)_{2} \mathrm{CH}\right]+\mathrm{Me}_{2} \mathrm{MCl} \stackrel{-80^{\circ} \mathrm{C}}{\longrightarrow}} \\
{\left[\mathrm{Me}_{2} \mathrm{M}\left(2-\mathrm{NC}_{5} \mathrm{H}_{4}\right)_{2} \mathrm{CH}\right]+\mathrm{LiCl}} \\
\text { 5: } \mathrm{M}=\mathrm{Al} ; \text { in } \mathrm{Et}_{2} \mathrm{O} \\
\text { 6: } \mathrm{M}=\mathrm{Ga} ; \text { in toluene }
\end{gathered}
$$

5 and 6 can be synthesized using a second route. Reacting bis(2-(pyridyl)methane directly with $\mathrm{Me}_{3} \mathrm{Al}$ or $\mathrm{Me}_{3} \mathrm{Ga}$ yields the product and methane.

Crystal Structure of 1 . As in the structures of $\mathrm{Ph}_{2}$ $\left(2-\mathrm{NC}_{5} \mathrm{H}_{4}\right) \mathrm{CLi} \cdot 2 \mathrm{Et}_{2} \mathrm{O}^{2}$, the lithium atom in 1 is not coordinated to the central deprotonated carbon atom (Figure 1; Table 1), but it is bound to both nitrogen atoms of the pyridyl rings. The $\mathrm{Li}-\mathrm{N}$ distances of 196.6 and $197.3 \mathrm{pm}$ are similar to those in lithium amides, ${ }^{14}$ which might be taken as the first hint that the derivatives discussed here are amides rather than carbanioncontaining compounds.

The chelating anion is essentially planar. The mean deviation from the plane of the eleven carbon and two nitrogen atoms of the anion is only $4 \mathrm{pm}$. The lithium

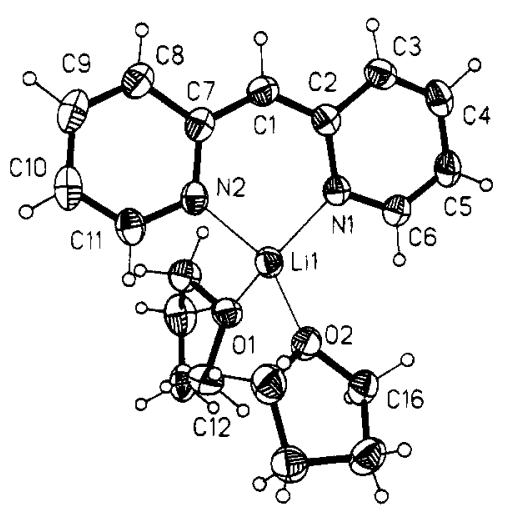

Figure 1. Crystal structure of 1 , anisotropic displacement parameters depicting $\mathbf{5 0 \%}$ probability.

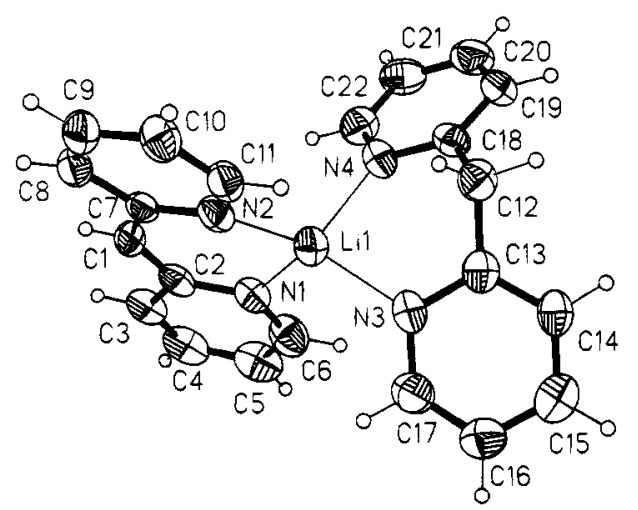

Figure 2. Crystal structure of 2, anisotropic displacement parameters depicting $50 \%$ probability. The uncoordinated lattice toluene molecule has been omitted for clarity.

atom also lies in that plane (deviation $3.6 \mathrm{pm}$ ). The basic structural parameters of the central carbon atom $\mathrm{C} 1\left(\mathrm{C} 1-\mathrm{C} 2\right.$ and $\mathrm{C} 1-\mathrm{C} 7,140.6 \mathrm{pm}$; $\left.2-\mathrm{C} 1-\mathrm{C} 7,130.9^{\circ}\right)$

\begin{tabular}{|c|c|c|c|c|c|c|c|c|c|c|c|}
\hline \multicolumn{2}{|l|}{1} & \multicolumn{2}{|l|}{2} & \multicolumn{2}{|l|}{3} & \multicolumn{2}{|l|}{4} & \multicolumn{2}{|l|}{5} & \multicolumn{2}{|l|}{6} \\
\hline $\begin{array}{l}\mathrm{C} 1-\mathrm{C} 2 \\
\mathrm{C} 1-\mathrm{C} 7\end{array}$ & $\begin{array}{l}140.6(3) \\
140.6(3)\end{array}$ & $\begin{array}{l}\mathrm{C} 1-\mathrm{C} 2 \\
\mathrm{C} 1-\mathrm{C} 7 \\
\mathrm{C} 12-\mathrm{C} 13 \\
\mathrm{C} 12-\mathrm{C} 18\end{array}$ & $\begin{array}{l}139.1(7) \\
141.0(6) \\
149.2(7) \\
150.5(7)\end{array}$ & $\begin{array}{l}\mathrm{C} 1-\mathrm{C} 2 \\
\mathrm{C} 1-\mathrm{C} 7 \\
\mathrm{C} 12-\mathrm{C} 13 \\
\mathrm{C} 12-\mathrm{C} 18\end{array}$ & $\begin{array}{l}141.7(4) \\
140.5(4) \\
140.6(4) \\
141.2(4)\end{array}$ & $\begin{array}{l}\mathrm{C} 1-\mathrm{C} 2 \\
\mathrm{C} 1-\mathrm{C} 7 \\
\mathrm{C} 20-\mathrm{C} 21 \\
\mathrm{C} 20-\mathrm{C} 26\end{array}$ & $\begin{array}{l}138.9(4) \\
141.2(4) \\
140.6(4) \\
141.0(4)\end{array}$ & $\begin{array}{l}\mathrm{C} 1-\mathrm{C} 2 \\
\mathrm{C} 1-\mathrm{C} 7\end{array}$ & $\begin{array}{l}139.1(7) \\
140.8(8)\end{array}$ & $\begin{array}{l}\mathrm{C} 1-\mathrm{C} 2 \\
\mathrm{C} 1-\mathrm{C} 7\end{array}$ & $\begin{array}{l}138.8(5) \\
140.3(5)\end{array}$ \\
\hline $\begin{array}{l}\mathrm{Li1}-\mathrm{N} 1 \\
\mathrm{Li} 1-\mathrm{N} 2 \\
\mathrm{Li} 1-\mathrm{O} 1 \\
\mathrm{Li} 1-\mathrm{O} 2\end{array}$ & $\begin{array}{l}196.6(4) \\
197.3(4) \\
199.4(4) \\
196.5(3)\end{array}$ & $\begin{array}{l}\mathrm{Li1}-\mathrm{N} 1 \\
\mathrm{Li}-\mathrm{N} 2 \\
\mathrm{Li1}-\mathrm{N} 3 \\
\mathrm{Li1}-\mathrm{N} 4\end{array}$ & $\begin{array}{l}196.0(9) \\
197.6(9) \\
207.1(9) \\
205.8(8)\end{array}$ & $\begin{array}{l}\mathrm{Li1}-\mathrm{N} 1 \\
\mathrm{Li1}-\mathrm{N} 2 \\
\mathrm{Li} 1-\mathrm{N} 3 \\
\mathrm{Li1}-\mathrm{N} 4 \\
\mathrm{Li2}-\mathrm{O}(\text { av) }\end{array}$ & $\begin{array}{l}201.5(5) \\
202.6(5) \\
200.1(5) \\
200.3(5) \\
236.5\end{array}$ & $\begin{array}{l}\mathrm{Li} 1-\mathrm{N} 1 \\
\mathrm{Li} 1-\mathrm{N} 2 \\
\mathrm{Li1}-\mathrm{N} 3 \\
\mathrm{Li1}-\mathrm{N} 4 \\
\mathrm{Na}-\mathrm{O} \text { (av) }\end{array}$ & $\begin{array}{l}201.0(5) \\
200.0(5) \\
200.4(5) \\
198.5(5) \\
237.3\end{array}$ & $\begin{array}{l}\text { Al1-N1 } \\
\text { Al1-N2 } \\
\text { Al1-C12 } \\
\text { Al1-C13 }\end{array}$ & $\begin{array}{l}190.8(4) \\
190.9(4) \\
195.3(6) \\
195.9(6)\end{array}$ & $\begin{array}{l}\mathrm{Ga} 1-\mathrm{N} 1 \\
\mathrm{Ga} 1-\mathrm{N} 2 \\
\mathrm{Ga} 1-\mathrm{C} 12 \\
\mathrm{Ga} 1-\mathrm{C} 13\end{array}$ & $\begin{array}{l}198.3(3) \\
197.9(3) \\
194.7(4) \\
195.9(4)\end{array}$ \\
\hline $\mathrm{C} 2-\mathrm{C} 1-\mathrm{C} 7$ & $130.9(2)$ & $\begin{array}{l}\mathrm{C} 2-\mathrm{C} 1-\mathrm{C} 7 \\
\mathrm{C} 13-\mathrm{C} 12-\mathrm{C} 18\end{array}$ & $\begin{array}{l}132.6(5) \\
115.0(4)\end{array}$ & $\begin{array}{l}\mathrm{C} 2-\mathrm{C} 1-\mathrm{C} 7 \\
\mathrm{C} 13-\mathrm{C} 12-\mathrm{C} 18\end{array}$ & $\begin{array}{l}130.3(2) \\
130.8(2)\end{array}$ & $\begin{array}{l}\mathrm{C} 2-\mathrm{C} 1-\mathrm{C} 7 \\
\mathrm{C} 21-\mathrm{C} 20-\mathrm{C} 26\end{array}$ & $\begin{array}{l}131.9(3) \\
130.4(2)\end{array}$ & $\mathrm{C} 2-\mathrm{C} 1-\mathrm{C} 7$ & $129.4(4)$ & $\mathrm{C} 2-\mathrm{C} 1-\mathrm{C} 7$ & $131.1(4)$ \\
\hline $\begin{array}{l}\mathrm{N} 1-\mathrm{Li} 1-\mathrm{N} 2 \\
\mathrm{~N} 1-\mathrm{Li} 1-\mathrm{O} 1 \\
\mathrm{~N} 1-\mathrm{Li} 1-\mathrm{O} 2 \\
\mathrm{~N} 2-\mathrm{Li} 1-\mathrm{O} 1 \\
\mathrm{~N} 2-\mathrm{Li1}-\mathrm{O} 2 \\
\mathrm{O} 1-\mathrm{Li} 1-\mathrm{O} 2\end{array}$ & $\begin{array}{l}96.4(2) \\
118.6(2) \\
115.3(2) \\
106.5(2) \\
122.3(2) \\
98.9(9)\end{array}$ & $\begin{array}{l}\text { N1-Li1-N2 } \\
\text { N1-Li1-N3 } \\
\text { N1-Li1-N4 } \\
\text { N2-Li1-N3 } \\
\text { N2-Li1-N4 } \\
\text { N3-Li1-N4 }\end{array}$ & $\begin{array}{l}97.1(4) \\
115.6(4) \\
110.6(4) \\
123.3(5) \\
117.7(4) \\
93.5(3)\end{array}$ & $\begin{array}{l}\text { N1-Li1-N2 } \\
\text { N1-Li1-N3 } \\
\text { N1-Li1-N4 } \\
\text { N2-Li1-N3 } \\
\text { N2-Li1-N4 } \\
\text { N3-Li1-N4 }\end{array}$ & $\begin{array}{l}92.6(2) \\
126.8(2) \\
107.9(2) \\
115.5(2) \\
123.2(2) \\
93.6(2)\end{array}$ & $\begin{array}{l}\text { N1-Li1-N2 } \\
\text { N1-Li1-N3 } \\
\text { N1-Li1-N4 } \\
\text { N2-Li1-N3 } \\
\text { N2-Li1-N4 } \\
\text { N3-Li1-N4 }\end{array}$ & $\begin{array}{l}93.6(2) \\
124.2(3) \\
112.7(2) \\
120.2(2) \\
113.5(2) \\
94.0(2)\end{array}$ & $\begin{array}{l}\mathrm{N} 1-\mathrm{A} 11-\mathrm{N} 2 \\
\mathrm{~N} 1-\mathrm{Al1}-\mathrm{C} 12 \\
\mathrm{~N} 1-\mathrm{Al1}-\mathrm{C} 13 \\
\mathrm{~N} 2-\mathrm{Al1}-\mathrm{C} 12 \\
\mathrm{~N} 2-\mathrm{Al1}-\mathrm{C} 13 \\
\mathrm{C} 12-\mathrm{Al1}-\mathrm{C} 13\end{array}$ & $\begin{array}{l}97.1(1) \\
109.7(4) \\
110.0(2) \\
110.2(2) \\
110.7(2) \\
117.4(2)\end{array}$ & $\begin{array}{l}\mathrm{N} 1-\mathrm{Gal}-\mathrm{N} 2 \\
\mathrm{~N} 1-\mathrm{Ga} 1-\mathrm{C} 12 \\
\mathrm{~N} 1-\mathrm{Ga} 1-\mathrm{C} 13 \\
\mathrm{~N} 2-\mathrm{Ga1}-\mathrm{C} 12 \\
\mathrm{~N} 2-\mathrm{Gal}-\mathrm{C} 13 \\
\mathrm{C} 12-\mathrm{Ga1}-\mathrm{C} 13\end{array}$ & $\begin{array}{l}94.9(1) \\
109.1(2) \\
108.8(2) \\
108.8(2) \\
109.9(2) \\
121.9(2)\end{array}$ \\
\hline
\end{tabular}
show that this atom is $\mathrm{sp}^{2}$-hybridized. The expected $\mathrm{C}-\mathrm{C}-\mathrm{C}$ bond angle of $120^{\circ}$ for an unstrained system is widened by the coordinated lithium atom. Obviously, there is no electron density accumulated at the central carbon atom. The two pyridyl rings are only twisted with respect to each other by $5.6^{\circ}$, suggesting that the anion is fully conjugated. Above and below that plane, the lithium atom is additionally coordinated by two thf molecules.

Crystal Structure of 2. In hydrocarbons the lithiation of the bis(2-(pyridyl)methane can be stopped halfway. Half an equivalent is deprotonated, while the other half acts as a nitrogen donor base (Figure 2; Table

Table 1. Selected Bond Lengths (pm) and Angles (deg) of 1-6 


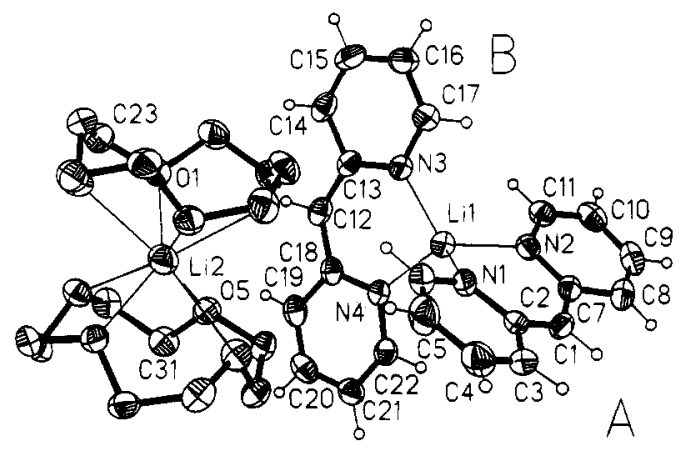

Figure 3. Crystal structure of 3, anisotropic displacement parameters depicting $50 \%$ probability. The hydrogen atoms of both crown ether molecules have been omitted for clarity.

1). The $\mathrm{Li}-\mathrm{N}$ distances of the metal to the anion are significantly shorter (196.0 and $197.6 \mathrm{pm}$ ) than those to the intact starting material molecule (207.1 and 205.8 $\mathrm{pm}$ ). Again, the anion is planar (mean deviation from the plane: $5.8 \mathrm{pm}$ ), but the lithium atom is $48.5 \mathrm{pm}$ out of that plane. The two pyridyl rings are twisted by only $7.6^{\circ}$. The two central $\mathrm{C}-\mathrm{C}$ bonds in the anion are in good agreement with the $\mathrm{C}-\mathrm{C}$ distances in an aromatic system (139.1 and $141.0 \mathrm{pm}$ ). Furthermore, the position of the single hydrogen atom at $\mathrm{C} 1$ was taken from the difference map and refined freely.

The conformation of the donating bis(2-pyridyl)methane is quite different. Not only is the angle of the normals to the planes of the two pyridyl rings $124.5^{\circ}$ but also the basic structural parameters of the central carbon atom indicate an $\mathrm{sp}^{3}$-type atom. The $\mathrm{C}-\mathrm{C}$ bonds are significantly longer (150.5 and $149.2 \mathrm{pm})$, hence in good accordance with a standard $\mathrm{C}\left(\mathrm{sp}^{3}\right)-\mathrm{C}\left(\mathrm{sp}^{2}\right)$ single bond of $151 \mathrm{pm} .{ }^{15}$ In addition, the $\mathrm{C}-\mathrm{C}-\mathrm{C}$ angle is more acute than that of the anion (115.0 compared to $132.6^{\circ}$ ). Again, the positions of the two hydrogen atoms at $\mathrm{C} 12$ were taken from the difference map and refined freely.

Crystal Structure of 3. 1 was reacted with 1 equiv of 12-crown-4 (eq 3), and in fact the presence of the crown ether removes the lithium atom 0.5 equiv of 1 , but the free anion is coordinated to the second half of 1 , removing the coordinated thf. Hence 1 reacts in the ratio $1: 1$ with crown ether to give the lithium lithiate 3. Up to now, only two related structures of this type have been known. ${ }^{16,17}$ A lithium atom coordinated to two neutral crown ether molecules gives the cation while the second lithium atom surrounded by two anions is part of the overall anion (Figure 3; Table 1).

(15) Rademacher, P. In Strukturen organischer Moleküle; Klessinger, M., Eds.; VCH: Weinheim, New York, 1987; p 56 f.

(16) Eaborn, C.; Hitchcock, P. B.; Smith, J. D.; Sullivan, A. C. J. Chem. Soc., Chem. Commun. 1983, 827.

(17) Pauer, F.; Rocha, J.; Stalke, D. J. Chem. Soc., Chem. Commun. $1991,1477$.

(18) Kottke, T.; Stalke, D. J. Appl. Crystallogr. 1993, 26, 615.

(19) (a) Jonas, K. Brauer, D. J.; Krüger, C.; Roberts, P. J.; Tsay, Y.H. J. Am. Chem. Soc. 1976, 98, 74. (b) Weiss, E.; Sauermann, G.; Thirase, G. Chem. Ber. 1983, 116, 74. (c) Clegg, W.; Mulvey, R. E.; Snaith, R.; Toogood, G. E.; Wade, K. J. Chem. Soc., Chem. Commun. 1986, 1740. (d) Furmanova, N. G.; Andrianiv, V. I.; Dobrzhanskii, G. F. Kristallografiya 1986, 31, 175. (e) Raston, C. L.; Whitaker, C. R.; White, A. H. Aust. J. Chem. 1988, 41, 823. (f) Schümann, U.; Weiss, E. Angew. Chem. 1988, 100, 573; Angew. Chem. Int., Ed. Engl. 1988, 27, 584. (g) Barr, D.; Clegg, W.; Mulvey, R. E.; Snaith, R. J. Chem. Soc., Chem. Commun. 1989, 57. (h) Williard, P. G.; Nichols, M. A. J. Am. Chem. Soc. 1991, 113, 9671 . (i) Freitag, S.; Kolodziejski, W.; Pauer, F.; Stalke, D. J. Chem. Soc., Dalton Trans. 1993, 3479. (j) Nichols, M. A.; Waldmüller, D.; Williard, P. G. J. Am. Chem. Soc. 1994, 116, 1153.

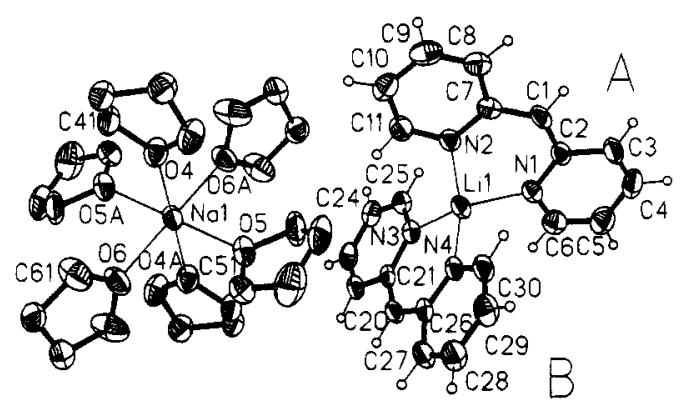

Figure 4. Crystal structure of 4, anisotropic displacement parameters depicting $50 \%$ probability. The hydrogen atoms of the thf molecules coordinated to sodium and the single lattice THF molecule have been omitted for clarity.

The Li-N distances in 3 are almost exactly halfway between the short $\mathrm{Li}-\mathrm{N}$ distances in the contact ion pairs of 1 and 2 and the long $\mathrm{Li}-\mathrm{N}$ donor distances in 2. The average value of $201.1 \mathrm{pm}$ in $\mathbf{3}$ shows the steric demand of two $\left(2-\mathrm{NC}_{5} \mathrm{H}_{4}\right) \mathrm{CH}$ anions coordinated to a single lithium cation. These two anions are significantly different. Anion A (Figure 3) deviates considerably from planarity: the mean deviation from the plane is 12.4 $\mathrm{pm}$, and the two pyridyl rings are twisted by $15.6^{\circ}$. Li1 is $73 \mathrm{pm}$ out of the plane of anion A. B is similar to the anions in 1 and 2: the mean deviation from the plane is only $5.0 \mathrm{pm}$, and the two pyridyl rings are only twisted by $6.1^{\circ}$. Li1 is only $15.5 \mathrm{pm}$ out of the plane of the anion. The $\mathrm{C} 1 \mathrm{mLi} 1 \mathrm{C} 12$ angle is $159.8^{\circ}$, and the planes of the anions are almost perpendicular $\left(82.3^{\circ}\right)$.

Crystal Structure of 4. Crystals of 4 were obtained at $-35^{\circ} \mathrm{C}$ from a THF solution. One of the low-melting single crystals $\left(\mathrm{mp}<-30^{\circ} \mathrm{C}\right)$ was selected and transferred to the diffractometer at $-80{ }^{\circ} \mathrm{C} .18$ To our knowledge 4 is the first example of a sodium lithiate, although a few mixed lithium/sodium metal organic complexes are known. ${ }^{19}$ Formally, only the $\mathrm{Li}$ (12-crown$4)_{2}$ cation in 3 is replaced by the $\mathrm{Na}\left(\right.$ thf $_{6}$ cation. $^{20}$

The two anions coordinated to the lithium atom in 4 are not as different (Figure 4, Table 1) as in 3. Both anions $A$ and $B$ are planar (mean deviation from the plane: $4.8 \mathrm{pm}$ in $\mathrm{A}$ and $2.4 \mathrm{pm}$ in $\mathrm{B}$ ), and the two pyridyl rings are only slightly twisted $\left(5.9^{\circ}\right.$ in $\mathrm{A}$ and $3.0^{\circ}$ in $\left.\mathrm{B}\right)$. While the lithium atom is $40.9 \mathrm{pm}$ out of the plane of anion A, it is only $8.9 \mathrm{pm}$ out of that of B. Both anions are almost orthogonal $\left(88.3^{\circ}\right.$ ) with respect to each other. The $\mathrm{Li} 1-\mathrm{C} 1-\mathrm{C} 20$ angle is $162.6^{\circ}$. The $\mathrm{Li}-\mathrm{N}$ distances (average $200.0 \mathrm{pm}$ ) are very similar to those of 3 , hence located between an $\mathrm{Li}-\mathrm{N}$ distance in a lithium amide and an $\mathrm{Li}-\mathrm{N}$ donor bond.

Apparently, two $\left(2-\mathrm{NC}_{5} \mathrm{H}_{4}\right)_{2} \mathrm{CH}$ anions accommodate a single $\mathrm{Li}$ cation very well; therefore this structural motif is present in 3 and 4 . This might be the reason why total metal exchange does not occur.

In the mixture of $\mathrm{RLi} / \mathrm{NaO}^{t} \mathrm{Bu},{ }^{21-23}$ the $\mathrm{R}^{-}$does not necessarily have to be a "classical" carbanion like $\mathrm{Me}^{-}$ or $\mathrm{Bu}^{-}$. With the right shape and basicity of the anion,

(20) (a) Schumann, H.; Genthe, W.; Hahn, E.; Hossain, M. B.; van der Helm, D. J. Organomet. Chem. 1986, 299, 67. (b) Chen, M.; Wu, G.; Wu, W.; Zhuang, S.; Huang, Z. Organometallics 1988, 7, 802. (c) Steiner, A; Stalke, D. Inorg. Chem. 1993, 32, 1977. (d) Bock, H. Näther, C.; Havlas, Z.; John, A.; Arad, C.; Angew. Chem. 1994, 106 931; Angew. Chem., Int. Ed. Engl. 1994, 33, 875.

(21) (a) Lochmann, L.; Popisil, J.; Lim, D. Tetrahedron Lett. 1966, 257. (b) Lochmann.; Petranek, J. Ibid. 1991, 32, 1483. (c) Lochmann, L.; Trekoval, J. J. Organomet. Chem. 1987, 326, 1. (d) Lochmann, L.; Lim, D. Ibid. 1971, 28, 153. (e) Lochmann, L. Ibid. 1989, 376, 1. 


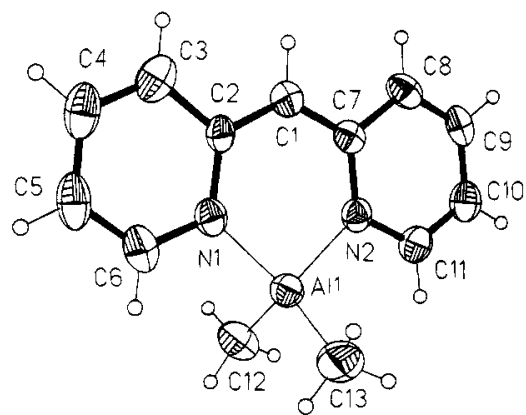

Figure 5. Crystal structure of 5, anisotropic displacement parameters depicting $50 \%$ probability.

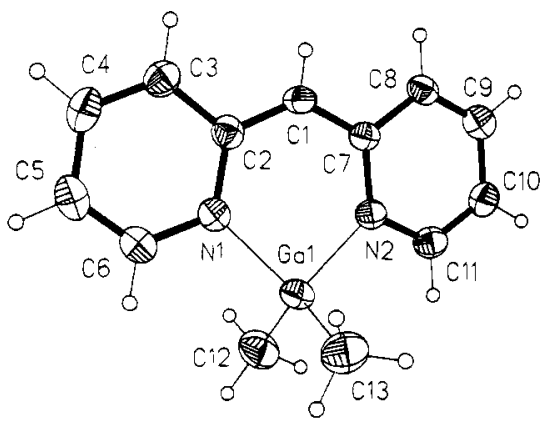

Figure 6. Crystal structure of 6, anisotropic displacement parameters depicting $50 \%$ probability.

selective transmetalation can be achieved. The very strong $\mathrm{Li}-\mathrm{O}$ interaction is often regarded as the driving force in this type of reaction. This now seems questionable, because in 4 only one $\mathrm{Li}-\mathrm{O}$ bond instead of the possible two is formed. Obviously, two chelating (2$\left.\mathrm{NC}_{5} \mathrm{H}_{4}\right)_{2} \mathrm{CH}$ anions are energetically more favorable than another $\mathrm{Li}-\mathrm{O}$ bond. Even the relatively labile $\mathrm{Na}$ $(\text { thf })_{6}$ cation is favored.

Crystal Structures of 5 and 6. In 5 , the (thf $)_{2} \mathrm{Li}$ unit of 1 is formally replaced by an $\mathrm{Me}_{2} \mathrm{Al}$ unit (Figure 5 , Table 1), and by an $\mathrm{Me}_{2} \mathrm{Ga}$ unit (Figure 6; Table 1) in 6. 5 adopts an unusual monomeric structure in the solid state. ${ }^{24-26}$ Like the alkali metals, the aluminum atom in $\mathbf{5}$ is chelated by the two nitrogen atoms within the pyridyl rings. It is only $1.1 \mathrm{pm}$ out of the plane of the anion, whereas the methyl groups are located above and below that plane. Again, the anion is planar (mean deviation $0.8 \mathrm{pm}$ ) and the two pyridyl rings are only twisted by $0.8^{\circ}$ with respect to each other. Hence, compared to the other anions discussed in this paper, that one in 5 fulfills the criterion of planarity almost ideally.

The Al-N bond lengths (Al1-N1, $190.8 \mathrm{pm} ; \mathrm{Al1}-\mathrm{N} 2$, $190.9 \mathrm{pm})$ are in good agreement with literature values; ${ }^{24}$ the $\mathrm{Al}-\mathrm{C}$ distances (Al1-C12, $195.3 \mathrm{pm} ; \mathrm{Al} 1-$ C13, $195.9 \mathrm{pm}$ ) are comparable with the distances in $\mathrm{Me}_{3} \mathrm{Al}^{27-29}$

(22) (a) Schlosser, M. J. Organomet Chem 1967, 8, 9 (b) Schlosser M.; Hartmann, J. J. Am. Chem. Soc. 1976, 98, 4674. (c) Stähle, M.; Hartmann, J.; Schlosser, M. Helv. Chim. Acta 1977, 60, 1730. (d) Schlosser, M.; Strunk, S. Tetrahedron Lett. 1984, 25, 741. (e) Schlosser, M.; Lehmann, R. Ibid. 1984, 25, 745.

(23) Harder, S.; Streitwieser, A., Jr. Angew. Chem. 1993, 105, 1108; Angew. Chem., Int. Ed. Engl. 1993, 32, 1066.

(24) Paciorek, K. J. L.; Nakahara, J. H.; Hoferkamp, L. A.; George, C.; Flippen-Anderson, J. L.; Gilardi, R.; Schmidt, W. R. Chem. Mater, $1991,3,82$.

(25) Mole, T.; Jeffrey, E. A. Organoaluminum Chemistry, Elsevier: New York, 1972

(26) Heine, A.; Stalke, D. Angew. Chem. 1992, 104, 941; Angew. Chem., Int. Ed. Engl. 1992, 31, 854.
The gallium atom in 6 is like the aluminum atom in 5 , coordinated to the ring nitrogen atoms. It is $29 \mathrm{pm}$ out of the plane of the anion. The gallium atom fits the bite of the ligand not as perfect as the aluminum does. The mean deviation from planarity is $4.7 \mathrm{pm}$, and the two pyridyl rings are twisted by $5.5^{\circ}$. The slightly longer $\mathrm{Ga}-\mathrm{N}$ bonds of 198.3 (N1) and 197.9 (N2) pm reflect the increase in the covalent radius of gallium compared with aluminum. In the $[\mathrm{GaN}]_{4}$ heterocubane skeleton of $\left[\mathrm{NHC}_{6} \mathrm{~F}_{5} \mathrm{Ga}(\mathrm{MesGa})_{3}\left(\mu_{3}-\mathrm{NC}_{6} \mathrm{~F}_{5}\right)_{4}\right]^{30}(\mathrm{Mes}=$ 2,4,6- $\mathrm{Me}_{3} \mathrm{C}_{6} \mathrm{H}_{2}$ ), the $\mathrm{Ga}-\mathrm{N}$ distances range from 196 to $206 \mathrm{pm}$. The $\mathrm{Ga}-\mathrm{C}$ distances (Ga1-C12, $194.7 \mathrm{pm}$; $\mathrm{Ga1}-\mathrm{C} 13,195.9 \mathrm{pm}$ ) are similar to the distances found in $\mathrm{Me}_{3} \mathrm{Ga}$ in the gas phase. ${ }^{31}$

\section{Structural Comparison}

The outstanding common feature of all discussed structures is that the anion exclusively coordinates the metals via the two nitrogen atoms. Furthermore, all anions are more or less ideally planar.

Thus, the central deprotonated carbon atom is to be regarded as $\mathrm{sp}^{2}$-hybridized without any negative charge being accumulated. Hence, the mesomeric form $\mathbf{c}$ is
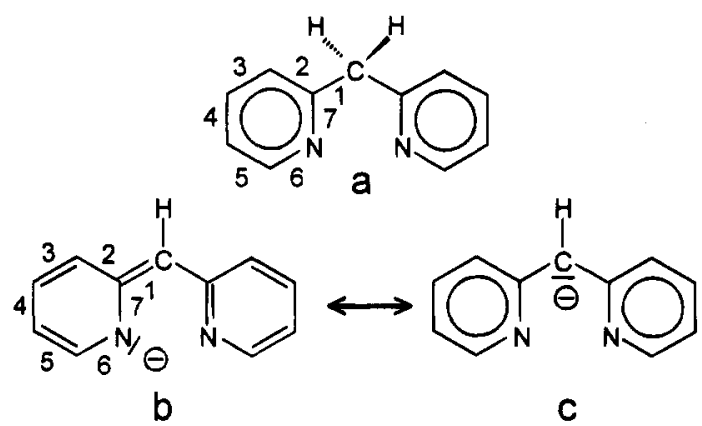

$\begin{array}{cccccccc} & \mathbf{1} & \mathbf{2} & \mathbf{3} & \mathbf{4} & \mathbf{5} & \mathbf{6} & \mathbf{7} \\ \mathbf{a} & 149.9 & 138.0 & 137.5 & 137.2 & 137.1 & 133.1 & 134.8 \\ \mathbf{b} & 140.4 & 142.7 & 135.6 & 139.1 & 136.3 & 134.9 & 136.8\end{array}$

unsuitable for describing the anion in an adequate way. All experiments prove that $\mathbf{b}$ is the form which contributes most. The average bond lengths show that the double bonds are localized in positions 1,3 , and 5 (averages of sixteen equivalent bonds in eight anions). The $\mathrm{N}-\mathrm{C}$ bonds are lengthened significantly, indicating accumulation of negative charge on nitrogen. Compared with the donating $\left(2-\mathrm{NC}_{5} \mathrm{H}_{4}\right)_{2} \mathrm{CH}_{2}$ in 2 (depicted in a), the central $\mathrm{C}-\mathrm{C}$ bond is considerably shortened by 10 pm. A shows delocalization within the aromatic system.

The $\mathrm{C}-\mathrm{C}$ bond between the central carbon atom and the ipso carbon atom of the alkali metal $\eta^{6}$-coordinated phenyl ring in $\mathrm{Ph}_{3} \mathrm{CK} \cdot \mathrm{pmdeta} / \mathrm{thf}$ (pmdeta $=\mathrm{MeN}\left(\mathrm{CH}_{2-}\right.$ $\left.\left.\mathrm{CH}_{2} \mathrm{NMe}_{2}\right)_{2}\right),\left[\mathrm{Ph}_{3} \mathrm{CRb} \text { pmdeta }\right]_{\infty}$, and [Ph $\mathrm{PCs}_{3} \mathrm{Cm}$ deta $]_{\infty}{ }^{1}$ is shortened on average by $2.5 \mathrm{pm}$, while the one to the ipso carbon atom of the pyridyl ring in $\mathrm{Ph}_{2}\left(2-\mathrm{NC}_{5} \mathrm{H}_{4}\right)$ $\mathrm{CLi} \cdot 2 \mathrm{Et}_{2} \mathrm{O}, \mathrm{Ph}_{2}\left(2-\mathrm{NC}_{5} \mathrm{H}_{4}\right) \mathrm{CNa} \cdot 3$ thf, and $\mathrm{Ph}_{2}\left(2-\mathrm{NC}_{5} \mathrm{H}_{4}\right)-$

(27) Vranka, R. G.; Amma, E. L. J. Am. Chem. Soc. 1967, 89, 3121 (28) Byram, S. K.; Fawcett, J. K; Nyburg, S. C.; O'Brien, R. J. J. Chem. Soc., Chem. Commun. 1970, 16.

(29) Huffman, J. C.; Streib, W. E. J. Chem. Soc., Chem. Commun. $1971,911$.

(30) Belgardt, T.; Waezsade, S. D.; Roesky, H. W.; Gornitzka, H.; Häming, L.; Stalke, D. Inorg. Chem., in press.

(31) Beagley, B.; Schmidling, D. G.; Steer, I. A. J. Mol. Struct. 1974, 21,437 . 
Table 2. Crystal Data for 1-6

\begin{tabular}{|c|c|c|c|c|c|c|}
\hline & 1 & 2 & 3 & 4 & 5 & 6 \\
\hline $\begin{array}{l}\text { formula } \\
\text { fw }\end{array}$ & $\begin{array}{l}\mathrm{C}_{19} \mathrm{H}_{25} \mathrm{LiN}_{2} \mathrm{O}_{2} \\
320.4\end{array}$ & $\begin{array}{l}{\left[\mathrm{C}_{22} \mathrm{H}_{19} \mathrm{LiN}_{4}\right] \mathrm{C}_{7} \mathrm{H}_{8}} \\
438.5\end{array}$ & $\begin{array}{l}\mathrm{C}_{38} \mathrm{H}_{50} \mathrm{Li}_{2} \mathrm{~N}_{4} \mathrm{O}_{8} \\
704.7\end{array}$ & $\begin{array}{l}\mathrm{C}_{50} \mathrm{H}_{74} \mathrm{LiN}_{4} \mathrm{NaO}_{7} \\
873.1\end{array}$ & $\begin{array}{l}\mathrm{C}_{13} \mathrm{H}_{15} \mathrm{AlN}_{2} \\
226.3\end{array}$ & $\begin{array}{l}\mathrm{C}_{13} \mathrm{H}_{15} \mathrm{GaN}_{2} \\
269.0\end{array}$ \\
\hline cryst syze (mm) & $0.8 \times 0.6 \times 0.5$ & $0.4 \times 0.4 \times 0.3$ & $0.5 \times 0.4 \times 0.4$ & $0.4 \times 0.4 \times 0.3$ & $0.4 \times 0.3 \times 0.3$ & $0.4 \times 0.2 \times 0.2$ \\
\hline space group & $P 2{ }_{1}{ }_{1} 2_{1}$ & $P 2_{1} / c$ & $P 2_{1} / c$ & $P \overline{1}$ & $P_{c a 2}$ & Pbcn \\
\hline$a(\mathrm{pm})$ & $970.4(1)$ & $1395.8(3)$ & $1194.1(6)$ & $1132.4(5)$ & $1281.7(1)$ & $2715.1(5)$ \\
\hline$b(\mathrm{pm})$ & $1305.3(1)$ & $1251.3(4)$ & $2404.9(12)$ & $1407.3(7)$ & $793.1(1)$ & $705.3(1)$ \\
\hline$c(\mathrm{pm})$ & $1354.5(3)$ & $1420.5(3)$ & $1320.8(7)$ & $1788.5(9)$ & $1227.8(1)$ & $1321.4(3)$ \\
\hline$\alpha(\mathrm{deg})$ & 90 & 90 & 90 & $93.49(2)$ & 90 & 90 \\
\hline$\beta(\mathrm{deg})$ & 90 & $95.85(3)$ & $101.74(3)$ & $106.73(2)$ & 90 & 90 \\
\hline$\gamma(\mathrm{deg})$ & 90 & 90 & 90 & $112.76(2)$ & 90 & 90 \\
\hline$V\left(\mathrm{~nm}^{3}\right)$ & $1.716(1)$ & $2.468(1)$ & $3.714(3)$ & $2.469(2)$ & $1.248(1)$ & $2.530(1)$ \\
\hline$Z$ & 4 & 4 & 4 & 2 & 4 & 8 \\
\hline temp $(\mathrm{K})$ & $153(2)$ & $153(2)$ & $153(2)$ & $153(2)$ & $193(1)$ & $153(2)$ \\
\hline$Q_{c}\left(\mathrm{Mg} \mathrm{m}^{-3}\right)$ & 1.240 & 1.180 & 1.260 & 1.175 & 1.204 & 1.412 \\
\hline$\mu\left(\mathrm{mm}^{-1}\right)$ & 0.079 & 0.070 & 0.087 & 0.085 & 0.137 & 2.149 \\
\hline$F(000)$ & 688 & 928 & 1504 & 944 & 480 & 1104 \\
\hline $2 \theta$ range $(\mathrm{deg})$ & $8-55$ & $8-45$ & $8-50$ & $8-45$ & $8-50$ & $8-55$ \\
\hline no. of reflns measd & 3712 & 3520 & 7744 & 8151 & 4209 & 4219 \\
\hline no. of unique reflns & 3264 & 3198 & 6512 & 6405 & 2214 & 2924 \\
\hline no. of restraints & 120 & 377 & 25 & 709 & 1 & 0 \\
\hline refined param & 317 & 386 & 541 & 688 & 149 & 150 \\
\hline$R 1[I>2 \sigma(I)]$ & 0.0398 & 0.0684 & 0.0502 & 0.0554 & 0.0584 & 0.0471 \\
\hline$w R 2^{a}$ (all data) & 0.1523 & 0.1891 & 0.1591 & 0.1554 & 0.1601 & 0.1169 \\
\hline$g 1 ; g 2^{b}$ & $0.035 ; 0.383$ & $0.050 ; 3.930$ & $0.050 ; 1.070$ & $0.078 ; 1.933$ & $0.090 ; 0.000$ & $0.049 ; 0.335$ \\
\hline highest diff peak $\left(10^{-6} \mathrm{e} \mathrm{pm}^{-3}\right)$ & 0.13 & 0.27 & 0.20 & 0.37 & 0.70 & 0.51 \\
\hline
\end{tabular}

CK.pmdeta/thf is shortened by $5.5 \mathrm{pm}$. The bond shortening in 1-6 is even more pronounced, possibly because of the missing third aromatic ring at the central carbon atom.

However, the anions in 1-6 are considered to be amides. The coordination behavior of those amides seems to be quite rigid. Because they are fully conjugated, the $\mathrm{N}-\mathrm{N}$ distance varies only between 286.1 (5) and 294.9 (2) pm. Thus they are comparable with other chelating amides like $\mathrm{Me}_{2} \mathrm{Si}\left(\mathrm{N}^{t} \mathrm{Bu}\right)^{2-}{ }_{32} \mathrm{PhC}\left(\mathrm{NSiMe}_{3}\right)_{2}{ }^{-33}$ $\mathrm{RS}(\mathrm{NR})_{2}{ }^{-34}$ and $\mathrm{Ph}_{2} \mathrm{P}\left(\mathrm{NSiMe}_{3}\right)_{2}-{ }^{20 \mathrm{c}}$ The bite of these ligands is not tunable to the metal. Varying the bite is achieved by using the heavier homologues of carbon like germanium and tin as the central atom between pyridyl or pyrazolyl rings. ${ }^{35}$

\section{Conclusion}

The alkali metals coordinated to the triphenylmethyl carbanion shift from the central carbon atom to the $\eta^{6}$ coordination of a ring as they become heavier. In the diphenylpyridylmethyl carbanion, the negative charge is almost entirely located on the nitrogen ring atom. The bis(pyridyl)methyl anions discussed here form amides, with nearly ideal coplanar pyridyl rings. Two amides surrounding a lithium atom seem energetically favor-

(32) For review: Veith, M. Angew. Chem. 1987, 99, 1; Angew. Chem., Int. Ed. Engl. 1987, 26, 1.

(33) (a) Ergezinger, C.; Weller, F.; Dehnicke, K. Z. Naturforsch. 1988, 43B, 1119 and 1621. (b) Fenske, D.; Hartmann, E.; Dehnicke K. Ibid. 1988, 43B, 1611. (c) Maier, S.; Hiller, W.; Strähle, J.; Ergezinger, C.; Dehnicke, K Ibid. 1988, 43B, 1628. (d) Hey, E.; Ergezinger, C.; Dehnicke, K. Ibid. 1988, 43B, 205 and 1679. (e) Hiller, W.; Strähle, J.; Zinn, A.; Dehnicke, K. Ibid. 1989, 44B, 999; (f) Fenske, D.; Baum, G.; Zinn, A.; Dehnicke, K. Ibid. 1990, 45B, 1273. (g) Stalke,

D.; Wedler, M.; Edelmann, F. T. J. Organomet. Chem. 1992, 431, C1

(34) (a) Pauer, F.; Stalke, D. J. Organomet. Chem. 1991, 418, 127. (b) Pauer, F.; Rocha, J.; Stalke, D. J. Chem. Soc., Chem. Commun. 1991, 1477. (c) Edelmann, F. T.; Knösel, F.; Pauer, F.; Stalke, D.; Bauer, W. J. Organomet. Chem. 1992, 438, 1. (d) Freitag, S.; Kolodziejski, W.; Pauer, F.; Stalke, D. J. Chem. Soc., Dalton Trans. 1993, 3779

(35) (a) Steiner, A.; Stalke, D. J. Chem. Soc., Chem. Commun. 1993, 444 and 1702. (b) Steiner, A.; Stalke, D. Inorg. Chem., submitted for publication. able, stabilizing a lithium lithiate and a sodium lithiate. The two group 13 metals aluminum and gallium are coordinated in the same way as the alkali metals. The very similar radii of lithium, aluminum, and gallium match the bite of the ligand very well. The bigger sodium is not coordinated to the bis(pyridyl)methyl anion.

\section{Experimental Section}

All manipulations were performed under an inert atmosphere of dry nitrogen gas with Schlenk techniques or in an argon drybox. Solvents were dried over $\mathrm{Na} / \mathrm{K}$ alloy and distilled prior to use.

NMR spectra were obtained with a Bruker MSL 400 or AM 250 instrument. All NMR spectra were recorded in benzene$d_{6}$, toluene- $d_{8}$, or THF- $d_{8}$ with $\mathrm{SiMe}_{4}, \mathrm{LiCl}$, and $\mathrm{NaCl}$ as external standards. EI mass spectra were measured on Finnigan MAT 8230 or Varian MAT CH 5 instruments. Elemental analyses were obtained from the Analytisches Labor des Instituts für Anorganische Chemie der Universität Göttingen.

1: $0.68 \mathrm{~g}$ (4 mmol) of $\mathrm{H}_{2} \mathrm{C}\left(2-\mathrm{NC}_{5} \mathrm{H}_{4}\right)_{2}$ in $25 \mathrm{~mL}$ of THF was reacted with the equimolar amount of ${ }^{n} \mathrm{BuLi}(1.74 \mathrm{~mL}$ of a 2.3 $\mathrm{M}$ solution) at $-80^{\circ} \mathrm{C}$. Evaporating off the solvent gives an orange precipitate, which was washed twice with $10 \mathrm{~mL}$ of pentane. Crystallization from THF yielded crystals suitable for X-ray diffraction. Yield: $0.47 \mathrm{~g} ; 67 \%$. Mp: $40{ }^{\circ} \mathrm{C}$; decomposition at $T \geq 70{ }^{\circ} \mathrm{C}$. ${ }^{1} \mathrm{H}$ NMR (THF- $d_{8}$, room temperature): $\delta 1.77,3.58$ (thf), 4.63 (s, H1), 5.80 (ddd, ${ }^{3} J_{5,4}$ $6.61,{ }^{3} J_{5,6} 5.31,{ }^{4} J_{5,3} 1.11 \mathrm{~Hz}, \mathrm{H} 5$ ), 6.28 (ddd, ${ }^{3} J_{3,4} 8.65,{ }^{4} J_{3,5}$ $1.11,{ }^{4} J_{3,1} 1.11 \mathrm{~Hz}, \mathrm{H} 3$ ), 6.74 (ddd, ${ }^{3} J_{4,3} 8.65,{ }^{3} J_{4,5} 6.61,{ }^{4} J_{4,6}$ $1.91 \mathrm{~Hz}, \mathrm{H} 4), 7.59$ (dd, ${ }^{3} J_{6,5} 5.31,{ }^{4} J_{6,4} 1.91 \mathrm{~Hz}, \mathrm{H} 6$ ). ${ }^{13} \mathrm{C}$ NMR (THF/ $\mathrm{C}_{6} \mathrm{D}_{6}$, room temperature) $\delta 88.4(\mathrm{~s}, \mathrm{C} 1), 110.7(\mathrm{~s}, \mathrm{C5})$, 122.8 (s, C3), 135.6 (s, C4), $141.2(\mathrm{~s}, \mathrm{C} 6), 155.1(\mathrm{~s}, \mathrm{C} 2) .{ }^{7} \mathrm{Li}$ NMR (THF-d $d_{8}$, room temperature): $\delta 3.25$. MS $(70 \mathrm{eV}): \mathrm{m} / \mathrm{z}$ (\%) $169(100)\left(\mathrm{CH}\left(2-\mathrm{NC}_{5} \mathrm{H}_{4}\right)_{2}\right), 85$ (8) $\left(\mathrm{Li} 2-\mathrm{NC}_{5} \mathrm{H}_{4}\right), 78$ (8) (2$\mathrm{NC}_{5} \mathrm{H}_{4}$ ). Anal. Calcd (found): $\mathrm{C}, 71.23(68.86) ; \mathrm{H}, 7.86(7.73)$, $\mathrm{N}, 8.74$ (8.27).

2 was synthesized like 1 at $-80^{\circ} \mathrm{C}$, using toluene instead of THF as solvent. The reaction mixture was immediately transferred to a deep freeze $\left(-100^{\circ} \mathrm{C}\right)$. After 5 days, colorless crystals, suitable for X-ray structure analysis, were obtained. The crystals decompose at temperatures slightly higher than 
Table 3. Atomic Coordinates $\left(\times 10^{4}\right)$ and Equivalent Isotropic Displacement Parameters $\left(\mathbf{p m}^{2} \times \mathbf{1 0}^{-1}\right)$ for 1

\begin{tabular}{lrrrr} 
& \multicolumn{1}{c}{$x$} & $y$ & $z$ & $U(\mathrm{eq})^{a}$ \\
\hline C1 & $3385(2)$ & $8505(2)$ & $7507(2)$ & $34(1)$ \\
C2 & $2793(2)$ & $7869(1)$ & $6785(1)$ & $30(1)$ \\
C3 & $3665(2)$ & $7309(2)$ & $6131(2)$ & $39(1)$ \\
C4 & $3152(3)$ & $6703(2)$ & $5410(2)$ & $41(1)$ \\
C5 & $1737(2)$ & $6619(2)$ & $5309(2)$ & $39(1)$ \\
C6 & $934(2)$ & $7158(1)$ & $5949(2)$ & $34(1)$ \\
N1 & $1398(2)$ & $7770(1)$ & $6673(1)$ & $30(1)$ \\
C7 & $2778(2)$ & $9096(1)$ & $8258(1)$ & $32(1)$ \\
C8 & $3634(2)$ & $9712(2)$ & $8873(2)$ & $40(1)$ \\
C9 & $3097(3)$ & $10290(2)$ & $9605(2)$ & $44(2)$ \\
C10 & $1686(3)$ & $10291(2)$ & $9760(2)$ & $42(2)$ \\
C11 & $904(2)$ & $9694(2)$ & $9153(2)$ & $38(1)$ \\
N2 & $1390(2)$ & $9108(1)$ & $8416(1)$ & $32(1)$ \\
Li1 & $41(3)$ & $8421(2)$ & $7550(3)$ & $34(2)$ \\
O1 & $-1166(1)$ & $9518(1)$ & $7002(1)$ & $37(1)$ \\
C12 & $-2554(3)$ & $9797(2)$ & $7208(2)$ & $52(1)$ \\
C13 & $-2887(3)$ & $10688(2)$ & $6527(2)$ & $56(2)$ \\
C14 & $-1516(3)$ & $11003(2)$ & $6106(2)$ & $57(2)$ \\
C15 & $-499(2)$ & $10459(2)$ & $6750(2)$ & $43(1)$ \\
O2 & $-1394(1)$ & $7505(1)$ & $8069(1)$ & $37(1)$ \\
C16 & $-2339(2)$ & $6945(2)$ & $7445(2)$ & $38(1)$ \\
C17 & $-3432(3)$ & $6523(2)$ & $8110(2)$ & $49(2)$ \\
C18 & $-3427(2)$ & $7261(2)$ & $8974(2)$ & $46(1)$ \\
C19 & $-1934(3)$ & $7523(2)$ & $9059(2)$ & $48(1)$ \\
a & & & &
\end{tabular}
tensor.

${ }^{a} U(\mathrm{eq})$ is defined as one-third of the trace of the orthogonalized $\mathbf{U}_{i j}$

Table 4. Atomic Coordinates $\left(\times 10^{4}\right)$ and Equivalent Isotropic Displacement Parameters $\left(\mathrm{pm}^{2} \times \mathbf{1 0}^{-1}\right)$ for 2

\begin{tabular}{|c|c|c|c|c|}
\hline & $x$ & $y$ & $z$ & $U(\mathrm{eq})^{a}$ \\
\hline Li1 & $6363(6)$ & $1427(7)$ & $7145(5)$ & $45(2)$ \\
\hline $\mathrm{C} 1$ & $5612(4)$ & $-49(4)$ & $8734(3)$ & $37(1)$ \\
\hline $\mathrm{C} 2$ & $6582(4)$ & $-211(4)$ & $8627(3)$ & $37(1)$ \\
\hline C3 & $7105(4)$ & $-1022(4)$ & $9144(3)$ & $45(1)$ \\
\hline $\mathrm{C} 4$ & $8052(5)$ & $-1174(4)$ & $9092(4)$ & $56(2)$ \\
\hline C5 & $8540(4)$ & $-510(5)$ & $8499(4)$ & $61(2)$ \\
\hline C6 & $8004(4)$ & $241(5)$ & $7990(4)$ & $55(2)$ \\
\hline N1 & $7055(3)$ & $424(3)$ & $8030(2)$ & $40(1)$ \\
\hline C7 & $4945(3)$ & $735(4)$ & $8380(3)$ & $32(1)$ \\
\hline $\mathrm{C} 8$ & $4002(4)$ & $718(4)$ & $8679(3)$ & $41(1)$ \\
\hline $\mathrm{C} 9$ & $3343(4)$ & $1466(4)$ & $8379(3)$ & $46(1)$ \\
\hline C10 & $3584(4)$ & $2279(4)$ & $7779(3)$ & $45(1)$ \\
\hline C11 & $4499(4)$ & $2266(4)$ & $7517(3)$ & $42(1)$ \\
\hline $\mathrm{N} 2$ & $5177(3)$ & $1522(3)$ & $7790(2)$ & $37(1)$ \\
\hline $\mathrm{C} 12$ & $6220(4)$ & $2660(4)$ & $5246(4)$ & $45(1)$ \\
\hline $\mathrm{C} 13$ & $7059(4)$ & $3068(4)$ & $5880(3)$ & $40(1)$ \\
\hline $\mathrm{C} 14$ & $7706(4)$ & $3768(4)$ & $5546(3)$ & $43(1)$ \\
\hline C15 & $8452(4)$ & $4172(4)$ & $6153(4)$ & $53(2)$ \\
\hline $\mathrm{C} 16$ & $8547(4)$ & $3842(4)$ & $7081(4)$ & $54(2)$ \\
\hline C17 & $7883(4)$ & $3137(4)$ & $7362(4)$ & $51(2)$ \\
\hline N3 & $7142(3)$ & $2751(3)$ & $6792(3)$ & $42(1)$ \\
\hline C18 & $6243(3)$ & $1482(4)$ & $5039(3)$ & $39(1)$ \\
\hline C19 & $6250(4)$ & $1090(5)$ & $4130(3)$ & $49(1)$ \\
\hline $\mathrm{C} 20$ & $6255(4)$ & $8(5)$ & $3982(4)$ & $57(2)$ \\
\hline $\mathrm{C} 21$ & $6256(4)$ & $-664(4)$ & $4741(4)$ & $54(2)$ \\
\hline $\mathrm{C} 22$ & $6253(4)$ & $-217(4)$ & $5626(4)$ & $47(1)$ \\
\hline N4 & $6247(3)$ & $823(3)$ & $5791(2)$ & $39(1)$ \\
\hline
\end{tabular}

${ }^{a} U(\mathrm{eq})$ is defined as one-third of the trace of the orthogonalized $\mathbf{U}_{i j} \mathrm{j}$ tensor.

$-50{ }^{\circ} \mathrm{C}$, so one crystal was transferred to the diffractometer at ca. $-60^{\circ} \mathrm{C} .{ }^{18}$ Because of the high sensitivity of 2 , no other spectroscopic or analytical data could be obtained.

3: $1.7 \mathrm{~g}(10 \mathrm{mmol})$ of $\mathrm{H}_{2} \mathrm{C}\left(2-\mathrm{NC}_{5} \mathrm{H}_{4}\right)_{2}$ in $30 \mathrm{~mL}$ of hexane was reacted with $5.4 \mathrm{~mL}$ of ${ }^{n} \mathrm{BuLi}(1.85 \mathrm{M}$ solution) at -80 ${ }^{\circ} \mathrm{C}$. After stirring for $2 \mathrm{~h}, 2.0 \mathrm{~g}$ (11.3 mmol) of 12 -crown- 4 was added. The reaction mixture was warmed to room temperature, and the precipitate was redissolved by a small amount of THF. Storage at $-35^{\circ} \mathrm{C}$ yielded single crystals suitable for X-ray diffraction. Yield: $3 \mathrm{~g}, 85 \%$. Mp: $193{ }^{\circ} \mathrm{C}$; decomposition at $T \geq 215^{\circ} \mathrm{C}$. 3 is insoluble in hydrocarbons, and NMR investigations in THF show chemical shifts similar to those of 1. ${ }^{6} \mathrm{Li} \mathrm{CP} / \mathrm{MAS} \mathrm{NMR}\left({ }^{6} \mathrm{LiCO}_{3}\right.$ external standard): $\delta$
Table 5. Atomic Coordinates $\left(\times 10^{4}\right)$ and Equivalent Isotropic Displacement Parameters $\left(\mathrm{pm}^{2} \times \mathbf{1 0}^{-1}\right)$ for 3

\begin{tabular}{|c|c|c|c|c|}
\hline & $x$ & $y$ & $z$ & $U(\mathrm{eq})^{a}$ \\
\hline Li1 & 2651(3) & $3853(2)$ & $8328(3)$ & $37(2)$ \\
\hline $\mathrm{Cl}$ & $2574(2)$ & 3292(1) & $10566(2)$ & $33(1)$ \\
\hline $\mathrm{C} 2$ & $2702(2)$ & $3878(1)$ & $10604(2)$ & $31(1)$ \\
\hline C3 & $2659(2)$ & $4166(1)$ & $11533(2)$ & $39(1)$ \\
\hline C4 & $2811(3)$ & $4725(1)$ & $11608(2)$ & $50(2)$ \\
\hline C5 & $3014(3)$ & $5023(1)$ & $10761(2)$ & $53(2)$ \\
\hline C6 & $3042(2)$ & $4730(1)$ & $9879(2)$ & $41(2)$ \\
\hline $\mathrm{N} 1$ & $2885(2)$ & $4176(1)$ & $9764(1)$ & $32(1)$ \\
\hline C7 & $2767(2)$ & $2908(1)$ & $9819(2)$ & $32(1)$ \\
\hline $\mathrm{C} 8$ & 2791(2) & $2327(1)$ & $10054(2)$ & $40(1)$ \\
\hline C9 & $3082(2)$ & $1943(1)$ & $9397(2)$ & $46(1)$ \\
\hline $\mathrm{C} 10$ & $3333(2)$ & $2118(1)$ & $8459(2)$ & $44(1)$ \\
\hline C11 & $3250(2)$ & $2676(1)$ & $8243(2)$ & $38(1)$ \\
\hline $\mathrm{N} 2$ & $2967(2)$ & $3068(1)$ & $8873(2)$ & $33(1)$ \\
\hline $\mathrm{C} 12$ & $1748(2)$ & $4369(1)$ & $5976(2)$ & $36(2)$ \\
\hline C13 & $2936(2)$ & $4289(1)$ & $6259(2)$ & $33(2)$ \\
\hline C14 & $3641(3)$ & 4444(1) & $5548(2)$ & $42(2)$ \\
\hline $\mathrm{C} 15$ & 4799(3) & $4385(1)$ & $5797(2)$ & $50(2)$ \\
\hline $\mathrm{C} 16$ & $5309(2)$ & 4171(1) & $6760(3)$ & $52(2)$ \\
\hline $\mathrm{C} 17$ & $4598(2)$ & $4027(1)$ & $7408(2)$ & $45(2)$ \\
\hline $\mathrm{N} 3$ & $3456(2)$ & $4077(1)$ & $7204(2)$ & $34(1)$ \\
\hline $\mathrm{C} 18$ & $877(2)$ & $4292(1)$ & $6543(2)$ & $32(1)$ \\
\hline $\mathrm{C} 19$ & $-284(2)$ & $4419(1)$ & $6088(2)$ & $40(2)$ \\
\hline $\mathrm{C} 20$ & $-1131(2)$ & $4361(1)$ & $6628(2)$ & $43(1)$ \\
\hline C21 & $-869(2)$ & $4180(1)$ & $7655(2)$ & $40(1)$ \\
\hline $\mathrm{C} 22$ & $258(2)$ & $4062(1)$ & $8056(2)$ & $33(1)$ \\
\hline $\mathrm{N} 4$ & $1118(2)$ & $4102(1)$ & $7544(1)$ & $30(1)$ \\
\hline $\mathrm{Li} 2$ & $2048(4)$ & $6629(2)$ & $7873(4)$ & $41(2)$ \\
\hline 01 & 2648(1) & $6337(1)$ & $6300(1)$ & $43(1)$ \\
\hline $\mathrm{C} 23$ & $2925(2)$ & $6809(1)$ & $5740(2)$ & $47(2)$ \\
\hline C24 & $3617(2)$ & $7222(1)$ & $6454(2)$ & $47(2)$ \\
\hline $\mathrm{O} 2$ & $2980(1)$ & $7377(1)$ & $7208(1)$ & $40(1)$ \\
\hline $\mathrm{C} 25$ & $3626(2)$ & $7686(1)$ & $8053(2)$ & $43(1)$ \\
\hline $\mathrm{C} 26$ & $4357(2)$ & $7315(1)$ & $8831(2)$ & $41(1)$ \\
\hline $\mathrm{O} 3$ & $3618(1)$ & $6920(1)$ & $9158(1)$ & $35(1)$ \\
\hline $\mathrm{C} 27$ & $4202(2)$ & $6439(1)$ & $9640(2)$ & $42(1)$ \\
\hline $\mathrm{C} 28$ & $4377(2)$ & $6021(1)$ & $8847(2)$ & $44(1)$ \\
\hline $\mathrm{O} 4$ & $3276(1)$ & $5893(1)$ & $8241(1)$ & $35(1)$ \\
\hline $\mathrm{C} 29$ & $3319(2)$ & $5566(1)$ & $7343(2)$ & $40(2)$ \\
\hline C30 & $3516(2)$ & $5923(1)$ & $6467(2)$ & $48(2)$ \\
\hline 05 & $788(1)$ & $5945(1)$ & $7484(1)$ & $36(1)$ \\
\hline C31 & $-280(2)$ & $6081(1)$ & $6841(2)$ & $39(1)$ \\
\hline $\mathrm{C} 32$ & $-43(2)$ & $6504(1)$ & $6070(2)$ & $37(1)$ \\
\hline O6 & $536(1)$ & $6978(1)$ & $6584(1)$ & $35(1)$ \\
\hline C33 & $-200(2)$ & $7362(1)$ & $6957(2)$ & $38(1)$ \\
\hline C34 & $543(2)$ & $7705(1)$ & $7784(2)$ & $35(1)$ \\
\hline 07 & $1157(1)$ & $7358(1)$ & $8589(1)$ & $32(1)$ \\
\hline C35 & $504(2)$ & $7199(1)$ & $9332(2)$ & $37(1)$ \\
\hline C36 & $1186(2)$ & $6781(1)$ & $10043(2)$ & $39(2)$ \\
\hline 08 & $1442(1)$ & $6401(1)$ & $9495(1)$ & $37(1)$ \\
\hline C37 & $515(2)$ & $5916(1)$ & $9246(2)$ & $37(1)$ \\
\hline C38 & $694(2)$ & $5588(1)$ & $8330(2)$ & $36(1)$ \\
\hline
\end{tabular}

${ }^{a} U(\mathrm{eq})$ is defined as one-third of the trace of the orthogonalized $\mathbf{U}_{i j}$ tensor.

-2.5 (Li2; see Figure 3) and 3.3 (Li1; see Figure 3). MS (70 $\mathrm{eV}): m / z(\%) 169(100)\left(\mathrm{CH}\left(2-\mathrm{NC}_{5} \mathrm{H}_{4}\right)_{2}\right)$.

4: $0.77 \mathrm{~g}(8 \mathrm{mmol})$ of $\mathrm{NaO}^{t} \mathrm{Bu}$ and $1.40 \mathrm{~g}(8 \mathrm{mmol})$ of $\mathrm{Li}(2-$ $\left.\mathrm{NC}_{5} \mathrm{H}_{4}\right)_{2} \mathrm{CH}$ were stirred in $30 \mathrm{~mL}$ of $\mathrm{THF}$ at room temperature. The reaction mixture was directly transferred to a deep freeze. After 3 days at $-35{ }^{\circ} \mathrm{C}$, colorless crystals were obtained. Mp: ca. $-30^{\circ} \mathrm{C}$. All NMR data were obtained from the vacuum-dried THF-free powder (decomposition $T>270$ ${ }^{\circ} \mathrm{C}$ ). ${ }^{1} \mathrm{H}$ NMR (THF- $d_{8}$, room temperature): $\delta 4.61$ (s, H1), 5.70 (ddd, ${ }^{3} J_{5,4} 6.55,{ }^{3} J_{5,6} 5.30,{ }^{4} J_{5,3} 1.1 \mathrm{~Hz}, \mathrm{H} 5$ ), 6.23 (d, ${ }^{3} J_{3,4} 8.60$ $\mathrm{Hz}, \mathrm{H} 3$ ), 6.69 (ddd, ${ }^{3} J_{4,3} 8.60,{ }^{3} J_{4,5} 6.55,{ }^{4} J_{4,6} 1.99 \mathrm{~Hz}, \mathrm{H} 4$ ), 7.59 (dd, ${ }^{3} J_{6,5} 5.30,{ }^{4} J_{6,4} 1.99 \mathrm{~Hz}, \mathrm{H6}$ ). ${ }^{13} \mathrm{C}$ NMR (THF- $d_{8}$, room temperature): $\delta 87.8(\mathrm{~s}, \mathrm{C} 1), 105.9(\mathrm{~s}, \mathrm{C} 5), 120.1(\mathrm{~s}, \mathrm{C} 3), 132.8$ (s, C4), 148.1 (s, C6), 160.2 (s, C2). ${ }^{7} \mathrm{Li} \mathrm{NMR} \mathrm{(THF-} d_{8}$, room temperature): $\delta 2.34(\mathrm{~s}) .{ }^{23} \mathrm{Na} \mathrm{NMR}$ (THF- $d_{8}$, room temperature): $\delta-0.49(\mathrm{~s}, \mathrm{br}) . \mathrm{MS}(70 \mathrm{eV}): \mathrm{m} / z(\%) 368(10)$ $\left(\mathrm{M}^{+}\right.$- thf), $169(100)\left(\mathrm{CH}\left(2-\mathrm{NC}_{5} \mathrm{H}_{4}\right)_{2}\right), 79(30)\left(2-\mathrm{NC}_{5} \mathrm{H}_{5}\right)$. Anal. Calcd for $\left[\mathrm{Na}(\text { thf })_{3}\right]\left[\mathrm{Li}\left\{\left(2-\mathrm{NC}_{5} \mathrm{H}_{4}\right)_{2} \mathrm{CH}\right\}_{2}\right]$ (found): C, 69.78 
Table 6. Atomic Coordinates $\left(\times 10^{4}\right)$ and Equivalent Isotropic Displacement Parameters $\left(\mathrm{pm}^{2} \times 10^{-1}\right)$ for 4

\begin{tabular}{|c|c|c|c|c|}
\hline & $x$ & $y$ & $z$ & $U(\text { eq })^{a}$ \\
\hline Lil & $3005(5)$ & $1434(4)$ & $1947(3)$ & $37(1)$ \\
\hline $\mathrm{C} 1$ & $4761(3)$ & $381(2)$ & $1333(2)$ & $36(1)$ \\
\hline $\mathrm{C} 2$ & $4356(3)$ & $-25(2)$ & $1952(2)$ & $35(1)$ \\
\hline$C(3)$ & $4790(3)$ & $-783(2)$ & $2294(2)$ & $47(1)$ \\
\hline $\mathrm{C} 4$ & $4402(3)$ & $-1202(3)$ & 2891(2) & $54(1)$ \\
\hline C5 & $3577(4)$ & $-891(3)$ & $3190(2)$ & $54(1)$ \\
\hline C6 & $3189(3)$ & $-171(2)$ & $2847(2)$ & $46(1)$ \\
\hline $\mathrm{N} 1$ & $3543(2)$ & $271(2)$ & $2254(1)$ & $36(1)$ \\
\hline C7 & $4414(3)$ & $1061(2)$ & $856(2)$ & $34(1)$ \\
\hline $\mathrm{C} 8$ & $4963(3)$ & $1330(2)$ & $242(2)$ & 41(1) \\
\hline $\mathrm{C} 9$ & $4619(3)$ & $1960(3)$ & $-241(2)$ & $50(1)$ \\
\hline $\mathrm{Cl} 0$ & $3715(3)$ & $2354(2)$ & $-124(2)$ & $48(1)$ \\
\hline C11 & $3229(3)$ & $2084(2)$ & $480(2)$ & $43(1)$ \\
\hline $\mathrm{N} 2$ & $3545(2)$ & $1468(2)$ & $975(1)$ & $34(1)$ \\
\hline $\mathrm{C} 20$ & $2167(3)$ & $3019(2)$ & $2902(2)$ & $33(1)$ \\
\hline $\mathrm{C} 21$ & $1060(3)$ & $2167(2)$ & $2343(2)$ & $29(1)$ \\
\hline $\mathrm{C} 22$ & $-291(3)$ & $2061(2)$ & $2239(2)$ & $35(1)$ \\
\hline $\mathrm{C} 23$ & $-1393(3)$ & $1269(2)$ & $1706(2)$ & $41(1)$ \\
\hline C24 & $-1224(3)$ & $541(2)$ & $1242(2)$ & 41(1) \\
\hline $\mathrm{C} 25$ & $83(3)$ & $663(2)$ & $1359(2)$ & $38(1)$ \\
\hline N3 & $1212(2)$ & $1439(2)$ & $1887(1)$ & $32(1)$ \\
\hline $\mathrm{C} 26$ & $3578(3)$ & $3325(2)$ & $3101(2)$ & $31(1)$ \\
\hline $\mathrm{C} 27$ & $4510(3)$ & $4257(2)$ & $3676(2)$ & $42(1)$ \\
\hline $\mathrm{C} 28$ & $5878(3)$ & $4575(2)$ & $3872(2)$ & $50(1)$ \\
\hline $\mathrm{C} 29$ & $6372(3)$ & $3986(2)$ & $3513(2)$ & $49(1)$ \\
\hline $\mathrm{C} 30$ & $5440(3)$ & $3102(2)$ & $2966(2)$ & $40(1)$ \\
\hline $\mathrm{N} 4$ & $4086(2)$ & $2758(2)$ & $2753(1)$ & $32(1)$ \\
\hline $\mathrm{Nal}$ & 0 & 5000 & 0 & $38(1)$ \\
\hline $\mathrm{O} 4$ & $1287(2)$ & $5422(2)$ & $-863(1)$ & $48(1)$ \\
\hline C41 & $862(3)$ & $5734(3)$ & $-1598(2)$ & $49(1)$ \\
\hline $\mathrm{C} 42$ & $2117(3)$ & $6302(3)$ & $-1796(2)$ & $47(1)$ \\
\hline $\mathrm{C} 43$ & $2980(3)$ & $5736(3)$ & $-1455(2)$ & $54(1)$ \\
\hline $\mathrm{C} 44$ & 2598(3) & $5432(3)$ & $-738(2)$ & $59(1)$ \\
\hline O5 & $1943(2)$ & $5076(2)$ & $1034(1)$ & $52(1)$ \\
\hline C51 & $2984(12)$ & $5992(7)$ & $1568(8)$ & $49(3)$ \\
\hline C52 & $4220(11)$ & $5825(11)$ & $1855(8)$ & $83(5)$ \\
\hline C53 & $3912(11)$ & $4773(14)$ & $1406(18)$ & $65(5)$ \\
\hline C54 & $2402(4)$ & $4260(3)$ & $1093(2)$ & $65(1)$ \\
\hline O6 & $693(2)$ & $6792(2)$ & $540(1)$ & $55(1)$ \\
\hline C61 & $1295(4)$ & $7704(3)$ & $232(3)$ & $72(1)$ \\
\hline C62 & $837(3)$ & $8491(2)$ & $486(2)$ & $50(1)$ \\
\hline C63 & $243(4)$ & $8070(3)$ & $1120(2)$ & $57(1)$ \\
\hline C64 & $114(20)$ & $7009(11)$ & $1077(11)$ & $74(7)$ \\
\hline $\mathrm{Na} 2$ & 0 & 0 & 5000 & $32(1)$ \\
\hline 07 & $1237(2)$ & $-1025(2)$ & $5447(1)$ & $43(1)$ \\
\hline C71 & $2605(3)$ & $-794(3)$ & $5484(2)$ & $50(1)$ \\
\hline C72 & $3025(3)$ & $-1554(3)$ & $5922(2)$ & $48(1)$ \\
\hline C73 & $2072(3)$ & $-1904(3)$ & 6381(1) & $51(1)$ \\
\hline C74 & $785(3)$ & $-1883(2)$ & $5828(2)$ & $43(1)$ \\
\hline O8 & $534(2)$ & $859(2)$ & $6311(1)$ & $43(1)$ \\
\hline C81 & $1187(5)$ & $609(3)$ & $7027(2)$ & $73(1)$ \\
\hline C82 & $2092(4)$ & $1627(3)$ & $7594(2)$ & $60(1)$ \\
\hline $\mathrm{C} 83$ & $1527(3)$ & $2390(2)$ & $7279(2)$ & $50(1)$ \\
\hline C84 & $307(3)$ & $1731(2)$ & $6564(2)$ & $47(1)$ \\
\hline$O(9)$ & $1954(2)$ & $1356(2)$ & $4928(1)$ & $45(1)$ \\
\hline C91 & $2850(11)$ & $2238(8)$ & $5547(6)$ & $53(3)$ \\
\hline $\mathrm{C} 92$ & $4093(3)$ & 2793(3) & $5335(2)$ & $64(1)$ \\
\hline $\mathrm{C} 93$ & $4080(3)$ & $1945(3)$ & $4769(2)$ & $54(1)$ \\
\hline C94 & 2581(3) & $1265(2)$ & $4357(2)$ & $45(1)$ \\
\hline
\end{tabular}

${ }^{a} U(\mathrm{eq})$ is defined as one-third of the trace of the orthogonalized $\mathbf{U}_{i j}$ tensor.

(62.54); H, $7.24(6.56) ; \mathrm{N}, 9.58$ (9.77). This approximation suggests that THF might not leave the crystals in a stoichiometric amount when they are taken out of the mother liquor at low temperatures.

5 can be synthesized in two different ways. Firstly, $0.17 \mathrm{~g}$ (1 mmol) of $\mathrm{H}_{2} \mathrm{C}\left(2-\mathrm{NC}_{5} \mathrm{H}_{4}\right)_{2}$ in $20 \mathrm{~mL}$ of diethyl ether was reacted with $0.44 \mathrm{~mL}$ of ${ }^{n} \mathrm{BuLi}\left(2.3 \mathrm{M}\right.$ solution) at $-80^{\circ} \mathrm{C}$ and warmed to $-50{ }^{\circ} \mathrm{C}$. After stirring for $1 \mathrm{~h}, 1 \mathrm{~mL}$ of a $1 \mathrm{M}$ solution of $\mathrm{Me}_{2} \mathrm{AlCl}$ in hexane was added, and the former pale yellow solution turned orange. It was then warmed to room temperature, stirred for $12 \mathrm{~h}$, and filtered through a glass frit. Half the amount of solvent was evaporated off. Storage of the
Table 7. Atomic Coordinates $\left(\times 10^{4}\right)$ and Equivalent Isotropic Displacement Parameters $\left(\mathrm{pm}^{2} \times 10^{-1}\right)$ for 5

\begin{tabular}{lrrrr}
\hline & $x$ & $y$ & $z$ & $U(\mathrm{eq})^{a}$ \\
\hline A11 & $1252(1)$ & $1718(1)$ & $4775(2)$ & $35(1)$ \\
C1 & $1207(4)$ & $5767(5)$ & $4850(5)$ & $37(2)$ \\
N1 & $2186(3)$ & $3359(5)$ & $4192(3)$ & $34(2)$ \\
C2 & $2051(4)$ & $5063(6)$ & $4301(4)$ & $30(3)$ \\
C3 & $2816(4)$ & $6167(7)$ & $3836(4)$ & $44(3)$ \\
C4 & $3647(5)$ & $5538(9)$ & $3285(4)$ & $48(3)$ \\
C5 & $3758(5)$ & $3800(8)$ & $3195(4)$ & $49(3)$ \\
C6 & $3024(4)$ & $2787(7)$ & $3648(4)$ & $42(3)$ \\
N2 & $294(3)$ & $3261(5)$ & $5426(3)$ & $33(2)$ \\
C7 & $375(5)$ & $4963(5)$ & $5389(5)$ & $29(3)$ \\
C8 & $-404(4)$ & $5954(7)$ & $5921(4)$ & $40(3)$ \\
C9 & $-1219(5)$ & $5170(6)$ & $6444(4)$ & $38(3)$ \\
C10 & $-1292(5)$ & $3446(6)$ & $6472(4)$ & $44(3)$ \\
C11 & $-536(4)$ & $2529(7)$ & $5954(4)$ & $39(3)$ \\
C12 & $1960(5)$ & $407(7)$ & $5900(5)$ & $54(4)$ \\
C13 & $581(5)$ & $470(7)$ & $3590(5)$ & $56(4)$
\end{tabular}

${ }^{a} U(\mathrm{eq})$ is defined as one-third of the trace of the orthogonalized $\mathbf{U}_{i j}$ tensor.

clear solution at $-35^{\circ} \mathrm{C}$ yielded orange crystals. In the second route, $0.68 \mathrm{~g}(4 \mathrm{mmol})$ of $\mathrm{H}_{2} \mathrm{C}\left(2-\mathrm{NC}_{5} \mathrm{H}_{4}\right)_{2}$ in $20 \mathrm{~mL}$ of diethyl ether was reacted at $-50{ }^{\circ} \mathrm{C}$ with $2 \mathrm{~mL}$ of a $2 \mathrm{M}$ solution of $\mathrm{Me}_{3} \mathrm{Al}$ in hexane. The reaction mixture was warmed to room temperature and stirred for $5 \mathrm{~h}$. After evaporating off the solvent, the precipitate was washed twice with $10 \mathrm{~mL}$ of hexane. The reaction yielded $0.22 \mathrm{~g}, 25 \%$, of pure product. Mp: $85{ }^{\circ} \mathrm{C}$. ${ }^{1} \mathrm{H}$ NMR $\left(\mathrm{C}_{6} \mathrm{D}_{6}\right.$, room temperature): $\delta-0.32(\mathrm{~s}$, $\mathrm{Me}$ ), 4.91 (s, H1), 5.79 (ddd, ${ }^{3} J_{5,4} 6.68,{ }^{3} J_{5,6} 6.16,{ }^{4} J_{5,3} 1.14 \mathrm{~Hz}$, H5), 6.30 (ddd, ${ }^{3} J_{3,4} 8.85,{ }^{4} J_{3,5} 1.14,{ }^{4} J_{3,1} 1.14 \mathrm{~Hz}, \mathrm{H} 3$ ), 6.55 (ddd, ${ }^{3} J_{4,3} 8.85,{ }^{3} J_{4,5} 6.68,{ }^{4} J_{4,6} 1.6 \mathrm{~Hz}, \mathrm{H} 4$ ), 7.27 (dd, ${ }^{3} J_{6,5} 6.16$ $\mathrm{Hz}, \mathrm{H6}$ ). ${ }^{13} \mathrm{C} \mathrm{NMR}$ ( $\mathrm{THF}, \mathrm{C}_{6} \mathrm{D}_{6}$, room temperature): $\delta 87.6(\mathrm{~s}$, C1), 106.0 (s, C5), 120.3 (s, C3), 132.7 (s, C4), 146.5 (s, C6), 159.0 (s, C2). Anal. Calcd (found): C, 69.01 (65.08); H, 6.68 (7.08); N, 12.38 (10.63).

6: A solution of $1.42 \mathrm{~g}(10.5 \mathrm{mmol})$ of $\mathrm{Me}_{2} \mathrm{GaCl}$ in $30 \mathrm{~mL}$ of toluene was added to a solution of $1.85 \mathrm{~g}(10.5 \mathrm{mmol})$ of $\mathrm{Li}$ $\left(2-\mathrm{NC}_{5} \mathrm{H}_{4}\right)_{2} \mathrm{CH}$ in $30 \mathrm{~mL}$ of toluene at $-80^{\circ} \mathrm{C}$. To complete the reaction, the mixture was stirred for $12 \mathrm{~h}$ at room temperature. The toluene was removed in vacuum, and the orange precipitate was redissolved in $20 \mathrm{~mL}$ of hexane. The resulting solution was filtered and storred at $-35^{\circ} \mathrm{C}$. After 2 days orange crystals were obtained, suitable for X-ray structure analysis. Yield: $0.25 \mathrm{~g}, 8.8 \%$. Mp: $72{ }^{\circ} \mathrm{C} .{ }^{1} \mathrm{H}$ NMR $\left(\mathrm{C}_{6} \mathrm{D}_{6}\right.$, room temperature): $\delta-0.52$ ( $\left.\mathrm{s}, \mathrm{Me}\right), 4.86(\mathrm{~s}, \mathrm{H} 1), 5.80$ (ddd, ${ }^{3} J_{5,4} 6.71,{ }^{3} J_{5,6} 6.02,{ }^{4} J_{5,3} 1.25 \mathrm{~Hz}, \mathrm{H5}$ ), 6.30 (dddd, ${ }^{3} J_{3,4}$ $8.78,{ }^{4} J_{3,5} 1.25,{ }^{3} J_{3,6} 0.93,{ }^{4} J_{3,1} 0.28 \mathrm{~Hz}, \mathrm{H3}$ ), 6.57 (dddd, ${ }^{3} J_{4,3}$ $8.78,{ }^{3} J_{4,5} 6.71,{ }^{4} J_{4,6} 1.70,{ }^{5} J_{4,1} 0.11 \mathrm{~Hz}, \mathrm{H} 4$ ), 7.06 (dddd, ${ }^{3} J_{5,6}$ $\left.6.02,{ }^{4} J_{6,4} 1.70,{ }^{5} J_{6,3} 0.93,{ }^{5} J_{6,1} 0.52 \mathrm{~Hz}, \mathrm{H} 6\right) .{ }^{13} \mathrm{C} \mathrm{NMR}\left(\mathrm{C}_{6} \mathrm{D}_{6}\right.$, room temperature): $\delta-8.0(\mathrm{~s}, \mathrm{Me}), 88.0(\mathrm{~s}, \mathrm{C} 1), 110.2(\mathrm{~s}, \mathrm{C} 5)$, 122.3 (s, C3), 134.9 (s, C4), 142.0 (s, C6), 155.2 (s, C2). MS $(70 \mathrm{eV}): \mathrm{m} / \mathrm{z}(\%) 268(8)\left(\mathrm{M}^{+}\right), 253(16)\left(\mathrm{M}^{+}-\mathrm{Me}\right), 238(10)$ $\left(\mathrm{M}^{+}-2 \mathrm{Me}\right), 169(100)\left(\mathrm{CH}\left(2-\mathrm{NC}_{5} \mathrm{H}_{4}\right)_{2}\right), 99(14)\left(\mathrm{GaMe}_{2}\right), 69(10)$ (Ga). Anal. Calcd (found): C, 58.05 (57.17); H, 5.62 (5.71); $\mathrm{N}, 10.41(9.80)$.

X-ray Measurements of 1-6. Crystal data for the six structures are presented in Table 2. All data were collected at low temperatures using an oil-coated shock-cooled crystal ${ }^{18}$ on a Stoe-Siemens AED with Mo $\mathrm{K} \alpha(\lambda=71.073 \mathrm{pm})$ radiation. The structures were solved by direct methods using SHELXS$90^{36}$ and refined with all data on $F^{2}$ with a weighting scheme of $w^{-1}=\sigma^{2}\left(F_{0}^{2}\right)+(g 1 \cdot P)^{2}+g 2 \cdot P$ with $P=\left(F_{0}^{2}+2 F_{c}^{2}\right) / 3$ using SHELXL-93. ${ }^{37}$ In 1 the positions of the hydrogen atoms of the anion were refined freely, whereas only the $\mathrm{C}-\mathrm{H}$ distances in the two thf molecules were restrained to be equal. In 2 a disordered toluene molecule is present in the lattice. It was refined by restraining the ADP's of neighboring atoms to be

(36) Sheldrick, G. M. Acta Crystallogr., Sect. A 1990, 46, 467.

(37) Sheldrick, G. M. SHELXL-93, program for crystal structure refinement, University of Göttingen, 1993. 
Table 8. Atomic Coordinates $\left(\times 10^{4}\right)$ and Equivalent Isotropic Displacement Parameters $\left(\mathrm{pm}^{2} \times 10^{-1}\right)$ for 6

\begin{tabular}{lcccc}
\hline & $x$ & $y$ & $z$ & $U(\mathrm{eq})^{a}$ \\
\hline Ga1 & $3483(1)$ & $5565(1)$ & $5805(1)$ & $32(1)$ \\
C1 & $4427(1)$ & $8174(6)$ & $6413(3)$ & $31(1)$ \\
C2 & $4035(1)$ & $8301(6)$ & $7085(3)$ & $31(1)$ \\
C3 & $4081(2)$ & $9392(6)$ & $7991(3)$ & $35(1)$ \\
C4 & $3704(2)$ & $9558(6)$ & $8652(3)$ & $44(1)$ \\
C5 & $3258(2)$ & $8628(7)$ & $8456(3)$ & $51(1)$ \\
C6 & $3225(2)$ & $7592(6)$ & $7607(3)$ & $45(1)$ \\
N1 & $3597(1)$ & $7377(5)$ & $6929(2)$ & $35(1)$ \\
C7 & $4465(1)$ & $7302(5)$ & $5462(3)$ & $27(1)$ \\
C8 & $4902(1)$ & $7535(5)$ & $4874(3)$ & $31(1)$ \\
C9 & $4947(2)$ & $6726(5)$ & $3947(3)$ & $35(1)$ \\
C10 & $4560(2)$ & $5614(6)$ & $3562(3)$ & $35(1)$ \\
C11 & $4152(1)$ & $5415(6)$ & $4142(3)$ & $35(1)$ \\
N2 & $4095(1)$ & $6218(5)$ & $5070(2)$ & $29(1)$ \\
C12 & $2920(1)$ & $6416(7)$ & $5012(4)$ & $51(1)$ \\
C13 & $3527(2)$ & $2977(6)$ & $6336(4)$ & $50(1)$
\end{tabular}

${ }^{a} U(\mathrm{eq})$ is defined as one-third of the trace of the orthogonalized $\mathbf{U}_{i j}$ tensor.

similar. In $\mathbf{3}$ the $\mathrm{C}-\mathrm{H}$ distances of the two anions were restrained to be equal. The hydrogen atoms of the crown ether molecules were geometrically idealized and refined using a riding model. In 4, three of the six coordinated thf molecules are disordered. The disorder was refined by using similar restraints. It seems worth noting that the uncoordinated THF molecule in the asymmetric unit is not disordered at all. Selected bond lengths and angles of 1-6 can be found in Table 1 , relevant crystallographic data for 1-6 are in Table 2, and fractional coordinates of 1-6 are presented in Tables 3-8.

Acknowledgment. Both authors wish to thank the Deutsche Forschungsgemeinschaft and the Fonds der Chemischen Industrie for financial support.

Supplementary Material Available: Tables of crystal data, fractional coordinates, bond lengths and angles, anisotropic displacement parameters, and hydrogen atom coordinates of 1-6 and fully labeled figures of 50\% anisotropic displacement parameters of the structures 1-6 (84 pages). Ordering information is given on any current masthead page. 